\title{
A decline of melanism in the peppered moth Biston betularia in The Netherlands
}

\author{
PAUL M. BRAKEFIELD
}

Section of Evolutionary Biology, Department of Population Biology, University of Leiden, Schelpenkade 14a, 2313 ZT Leiden, The Netherlands

\begin{abstract}
Melanic forms of the peppered moth Biston betularia were well established in The Netherlands by the end of the 19th century, indeed the first records of the black carbonaria form in 1867 are only about 20 years later than in England. Analysis of extensive sampling data collected by B. J. Lempke for a period of several years beginning in 1969 shows that carbonaria was at a frequency of about 60 to $70 \%$ in most of the country where epiphyte communities on trees were reduced due to the effects of air pollution. The pale typica and the three intermediate insularia forms were each at similar, low frequencies. Only in the extreme north and south-east of The Netherlands where epiphyte floras were richer was carbonaria at a lower frequency of less than $40 \%$. Samples collected from seven localities in 1988 show that carbonaria has dramatically declined to a frequency of less than $10 \%$. In contrast to England, the fully black form is being replaced not only by typica but also by the darkest of the insularia phenotypes. The decline in melanism coincides with a period of decreasing levels of sulphur dioxide and of increasing species diversity of lichens on trees.
\end{abstract}

KEY WORDS:-Biston betularia - peppered moth - industrial melanism - evolution polymorphism - natural selection - air pollution - epiphytes.

\section{CONTENTS}

Introduction

Surveys of Biston betularia in The Netherlands _ $\quad . \quad 328$

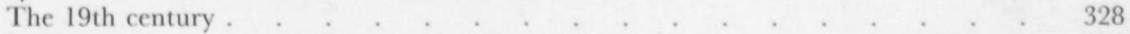

1969 to $1973 \ldots \ldots+\ldots 28$

1988 . . . . . . . . . . . . . . . . . 329

Discussion. . . . . . . . . . . 332

Acknowledgements . . . . . . . . . . . . . . . . . 333

References . . . . . . . . . 334

\section{INTRODUCTION}

Studies of industrial melanism have gained new impetus in recent years with the discovery of further evolutionary change occurring in the form of declines in the frequency of melanic forms of the peppered moth Biston betularia and the twospot ladybird beetle Adalia bipunctata in some urban environments in Britain (Clarke, Mani \& Wynne, 1985; Cook, Mani \& Varley, 1986; Howlett \& Majerus, 1987; Creed, 1971; Brakefield \& Lees, 1987). Such phenomena provide excellent opportunities for experimental analyses of natural selection involving both visual and non-visual effects of the major genes controlling the melanic 
polymorphisms. Insights from such studies will be critical to improving our rather rudimentary understanding of this classic example of the spread of adaptive phenotypes under the influence of natural selection (see Brakefield, 1987; Mani, 1990). Although both the moth and ladybird appear to be responding to decreases in air pollution, there are clearly important differences in the underlying mechanisms (see Brakefield \& Lees, 1987; Brakefield, 1987; Liebert \& Brakefield, 1987).

The present study provides a basic description of a recent decline in the frequency of the black carbonaria form of B. betularia in The Netherlands. Although this phenomenon tends to parallel the changes in Britain there are at the same time some interesting differences in detail. Unfortunately, unlike the monitoring studies of B. betularia at Caldy near Liverpool (Clarke el al., 1985) and of A. bipunctata in Birmingham (Creed, 1971; Brakefield \& Lees, 1987), data points are only available for the present-day and for some 15 to 20 generations (years) earlier.

\section{SURVEYS OF BISTON BETULARIA IN THE NETHERLANDS}

\section{The 19th century}

The first recorded observation of a black peppered moth in England was made in 1848 in Manchester (see Cook, 1981). The first record from The Netherlands is not much later (see Lempke, 1970). A mating pair of black moths was found on an elm tree at Breda in Noord-Brabant in 1867 (Heylaerts, 1870). The pairing is depicted in a plate by $\mathrm{S}$. van Vollenhoven. The discovery of a mating pair suggests that even by 1867 a dominant carbonaria allele was present at a substantial frequency in certain populations. In any case inspection of material in the Zoological Museum of Amsterdam shows that by the end of the 19th century melanic forms of $B$. betularia were well established in the greater part of The Netherlands. These melanic forms included not only carbonaria but each of the three main phenotypes recognized within the class of intermediate insularia melanics. These phenotypes are all determined by a series of alleles at the carbonaria locus. Lempke (1970) states that the earliest specimens of the four forms (see below) in the Zoological Museum of Amsterdam are dated 1871, 1895, 1888 and 1884 (in order of increasing melanization).

\section{9 to 1973}

B. J. Lempke working in the 1960 s recognized the value of a survey of B. betularia throughout The Netherlands. Entomologists were enlisted to send samples obtained in light traps to him for scoring and synthesis. Moths were scored after consultation with H.B.D. Kettlewell and study of Kettlewell's collection. Lempke distinguished five phenotypes: fully-black carbonaria; light typica; dark insularia $\left(\mathbf{I}_{3}\right)$, very dark with very light, or light specking; medium insularia $\left(\mathbf{I}_{2}\right)$ with substantial speckling; pale insularia $\left(\mathbf{I}_{1}\right)$, more black scaling than typica, especially on the body (see also Lempke, 1970). The sampling began in 1969 with collections at some localities extending over more than one year and at others, not commencing until a later year. Nearly all the samples date from the period 1969 to 1973 . A subset of the data for 1969 are included in Kettlewell 
TABLE 1. Percentage frequency of the five major non-melanic and melanic phenotypes of the peppered moth Biston betularia in pooled samples obtained in ten Dutch Provinces by B.J. Lempke from 1969 to 1973 (see text). Total sample sizes are also given

\begin{tabular}{lrrrrrr}
\hline & \multicolumn{5}{c}{ Percentage frequency } & Total sample \\
\cline { 2 - 5 } Province & typica & insul. 1 & insul. 2 & insul. 3 & carbonaria & size \\
\hline Friesland & 19.1 & 16.3 & 16.3 & 14.7 & 33.6 & 194 \\
Drenthe & 16.2 & 20.9 & 17.4 & 4.7 & 40.7 & 86 \\
Overijssel & 13.9 & 9.6 & 9.3 & 8.4 & 58.8 & 330 \\
Noord-Holland & 12.5 & 10.1 & 8.8 & 6.4 & 62.3 & 377 \\
Gelderland & 7.0 & 8.5 & 17.4 & 7.9 & 59.1 & 328 \\
Utrecht & 9.0 & 10.2 & 13.3 & 9.8 & 57.8 & 256 \\
Zuid-Holland & 4.3 & 7.8 & 9.9 & 7.3 & 70.7 & 232 \\
Noord-Brabant & 3.7 & 3.0 & 10.4 & 10.8 & 72.1 & 297 \\
Zeeland & 12.1 & 18.2 & 22.7 & 9.1 & 37.9 & 66 \\
Limburg & 2.3 & 4.5 & 10.8 & 9.6 & 72.9 & 1706 \\
\hline
\end{tabular}

(1973: table 6.1). Lempke most generously made the complete data set available for the present analysis.

A total of 4486 male B. betularia were obtained from 81 localities. However, 32 sites yielded less than ten moths and only 27 samples were of 40 or more moths. The samples provide a fairly thorough coverage of the country, only the extreme north (the Province of Groningen) being unrepresented. Preliminary examination of the data indicated broad regions of similar morph frequencies. Chi-square $\left(\chi^{2}\right)$ heterogeneity tests were applied to the frequency data for the localities grouped by Province or by contiguous groups of Provinces. The tests provided similar results when the phenotypes were grouped either by typica and all melanics or by typica:insularia:carbonaria. The larger samples from most of the individual Provinces are homogeneous $(P>0.05)$. This included Limburg in the south-east, the Province with the highest frequencies of carbonaria and the only one with more than two or three separate samples $\left(\chi^{2}=48.58\right.$, d.f. $=36$ and ten sites, $P>0.05)$. The data pooled by Province are given in Table 1. Each of the five phenotypes was collected throughout the country. The typica form and each of the three insularia phenotypes were of roughly similar abundance. The geographical variability in the frequency of carbonaria is illustrated in Fig. 1 together with an indication of the pattern of $\chi^{2}$ homogeneity across Provinces. Most of The Netherlands was characterized by high frequencies of carbonaria of about 60 or $70 \%$. However, Friesland and Drenthe in the north, and Zeeland in the extreme south-west had lower frequencies of around $40 \%$.

\section{8}

Large samples of $B$. betularia were obtained in May to July 1988 at several sites around Leiden and Rotterdam in the Province of Zuid-Holland by the use of assembly traps or the release of held virgin females onto trees (see Liebert \& Brakefield, 1987). In addition, smaller samples were obtained from central Amsterdam and Sint Nicolaasga in Friesland. The moths were scored in a manner as close as possible to that employed by Lempke and Kettlewell following inspection of many moths together with B. J. Lempke and T. G. 


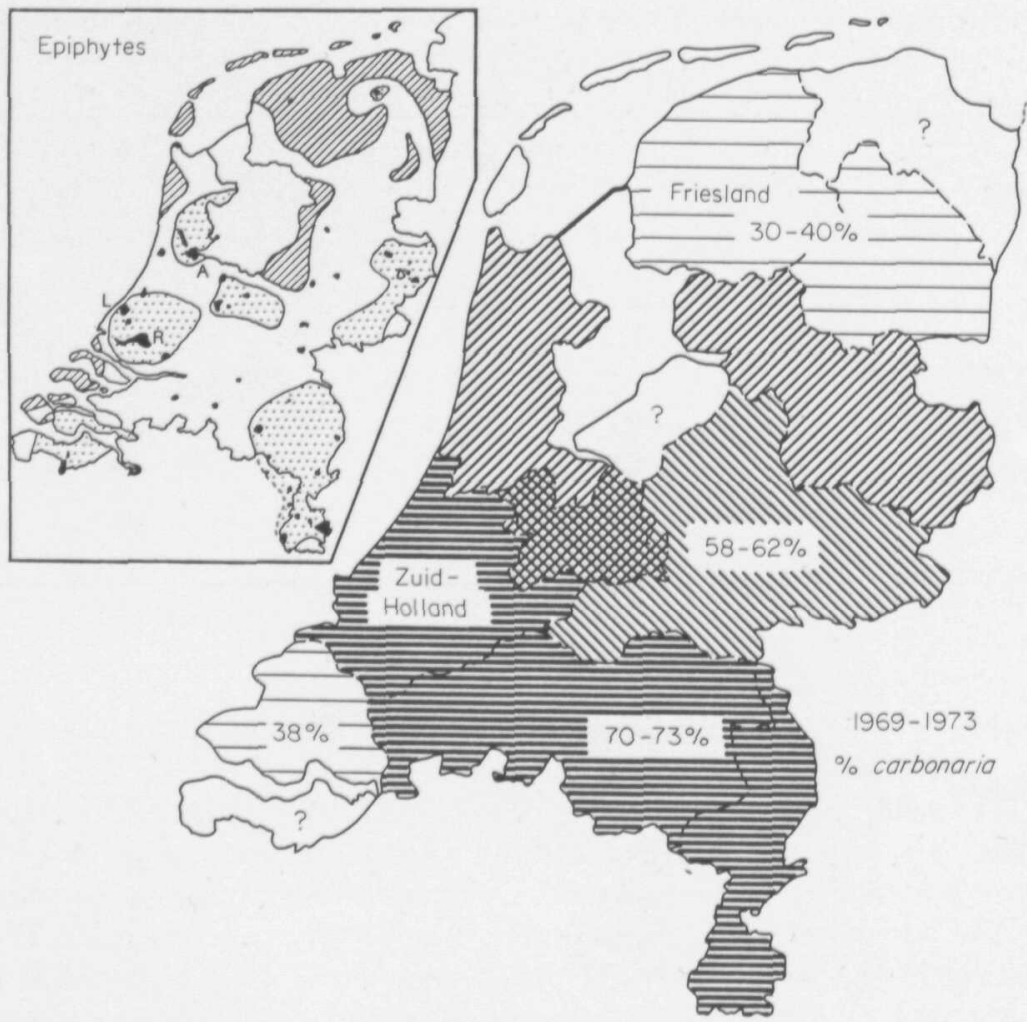

Figure 1. Map of The Netherlands showing the frequency of the carbonaria form of Biston betularia in the period 1969 to $1973(+)$. Broken lines show the borders between the Dutch Provinces, two of which are named. Shading indicates the pattern of homogeneity in morph-frequencies across Provinces (see text; data of B. J. Lempke). No samples were collected in the areas indicated by question marks. The inset map shows the epiphytic vegetation in the 1960 s with "deserts" dotted; transitional zone in white with poor to locally subnormal vegetation; normal or luxuriant areas hatched. Larger towns and main industrial areas are in black. Three cities near which samples were obtained in 1988 are indicated: A, Amsterdam; L, Leiden and R, Rotterdam (after Barkman, 1969).

TABLE 2. Numbers of the five major non-melanic and melanic phenotypes of the peppered moth Biston betularia in samples obtained from the indicated localities in 1988. The first three localities are in the vicinity of Leiden and the next two are just to the west of Rotterdam (see Fig. 1)

\begin{tabular}{|c|c|c|c|c|c|c|}
\hline \multirow{2}{*}{$\begin{array}{l}\text { Province/ } \\
\text { locality }\end{array}$} & \multicolumn{5}{|c|}{ Numbers } & \multirow[b]{2}{*}{ Total } \\
\hline & typica & insul. I & insul. 2 & insul. 3 & carbonaria & \\
\hline Zuid-Holland: & & & & & & \\
\hline Leiden & 138 & 23 & 31 & 116 & 32 & 340 \\
\hline Warmond & 51 & 4 & 6 & 31 & 5 & 97 \\
\hline Voorschoten & 53 & 10 & 8 & 17 & 10 & 98 \\
\hline Hoogvliet & 33 & 14 & 15 & 41 & 4 & 107 \\
\hline Schiedam N. & 56 & 19 & 17 & 54 & 5 & 151 \\
\hline $\begin{array}{l}\text { Noord-Holland: } \\
\text { Amsterdam }\end{array}$ & 18 & 2 & 8 & 6 & 3 & 37 \\
\hline $\begin{array}{l}\text { Friesland: } \\
\text { Sint Nicolaasga }\end{array}$ & 39 & 2 & 8 & 17 & 0 & 66 \\
\hline
\end{tabular}


- Liebert. It should, however, be recognized that the phenotypes intergrade and thus there is inevitably some subjectivity in assigning certain individuals to particular phenotypes. This is probably especially so for the boundaries between typica and insularia 1 and between insularia 3 and carbonaria (see also Lees \& Creed, 1977; Clarke, 1979). My own experience is that the body colouration is critical

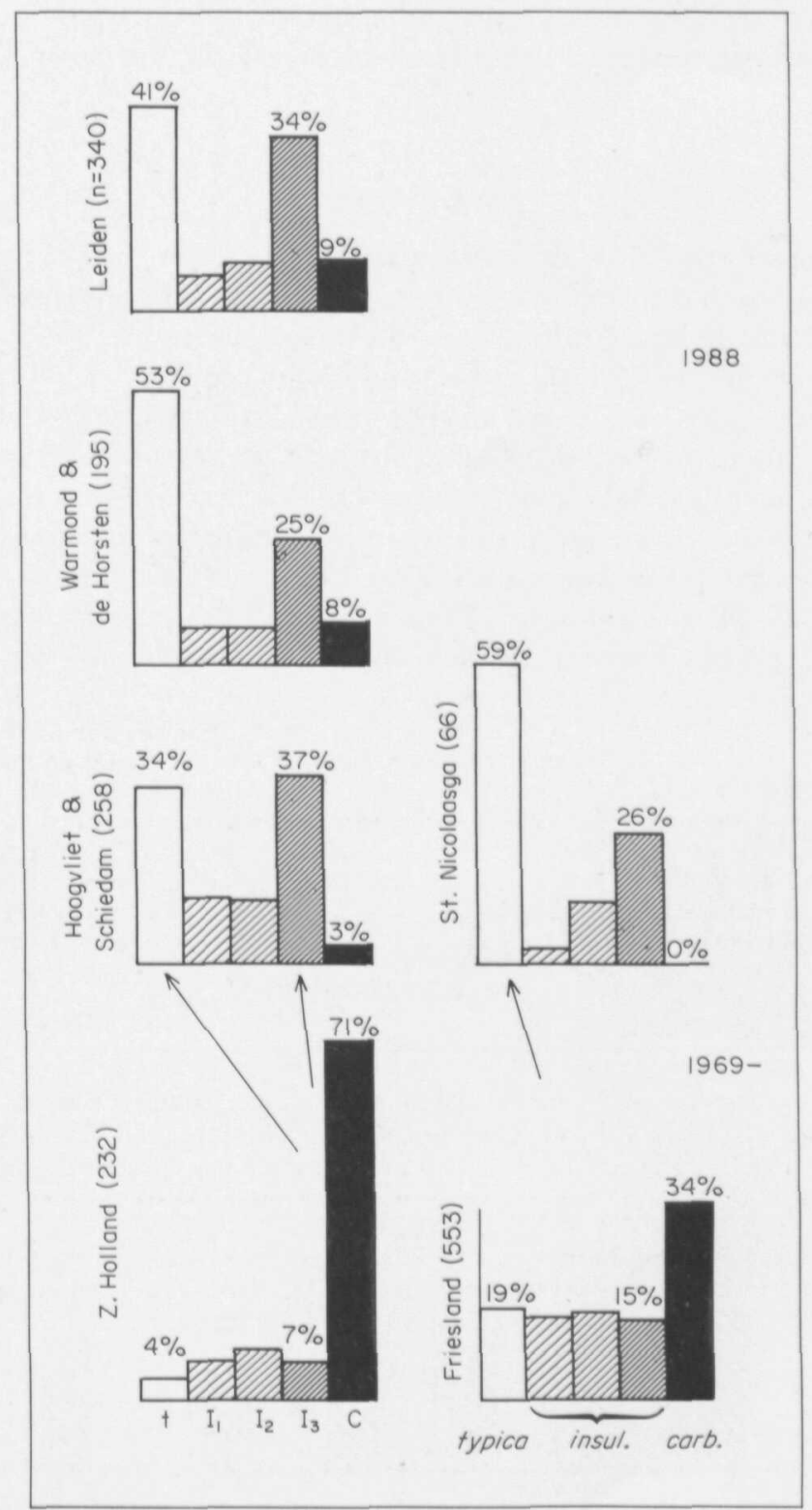

Figure 2. Comparison of morph frequencies in 1969-1973 (lower-most histograms) with those of 1988. The earlier samples are those pooled for each of two Dutch Provinces (see Fig. 1). The later samples from the same Provinces are either for individual sites or pooled for neighbouring localities (see Table 2). Percentage frequencies are indicated for the three morphs showing substantial changes in frequency. 
in the former case, and the presence or absence of a more or less complete ring of light white speckling on the upper hindwing, in the latter.

The frequency data for the samples collected in 1988 are given in Table 2. Figure 2 illustrates the dramatic changes which have occurred in less than 20 generations. In the area of Zuid-Holland and Noord-Holland the frequency of carbonaria has declined from about $70 \%$ to less than $10 \%$. Apparently it is being replaced not only by typica but also by the darkest form of insularia. The two paler forms of insularia have not changed substantially in frequency. There has also been a dramatic decline in carbonaria in Friesland but from initially lower levels.

\section{DISCUSSION}

The inset diagram in Fig. 1 shows that there was some spatial correspondence in the late 1960 s between melanism in B. betularia in The Netherlands and the growth of epiphytic lichen communities on trees (Barkman, 1969; see also map for 1972 given by de Wit, 1983). The only two regions with low frequencies $(<40 \%)$ of carbonaria were those in the north and extreme south-west with comparatively luxuriant lichen communities. The rest of the country which includes the major industrial conurbations was characterized by high frequencies of carbonaria of around 60 or $70 \%$ and by impoverished epiphyte growth (Fig. 1) and high levels of air pollution, especially sulphur dioxide (reports of the Dutch Rijksinstituut v. Volksgezondheid). Thus during this period B. betularia seems to have displayed classic industrial melanism with a correlation between air
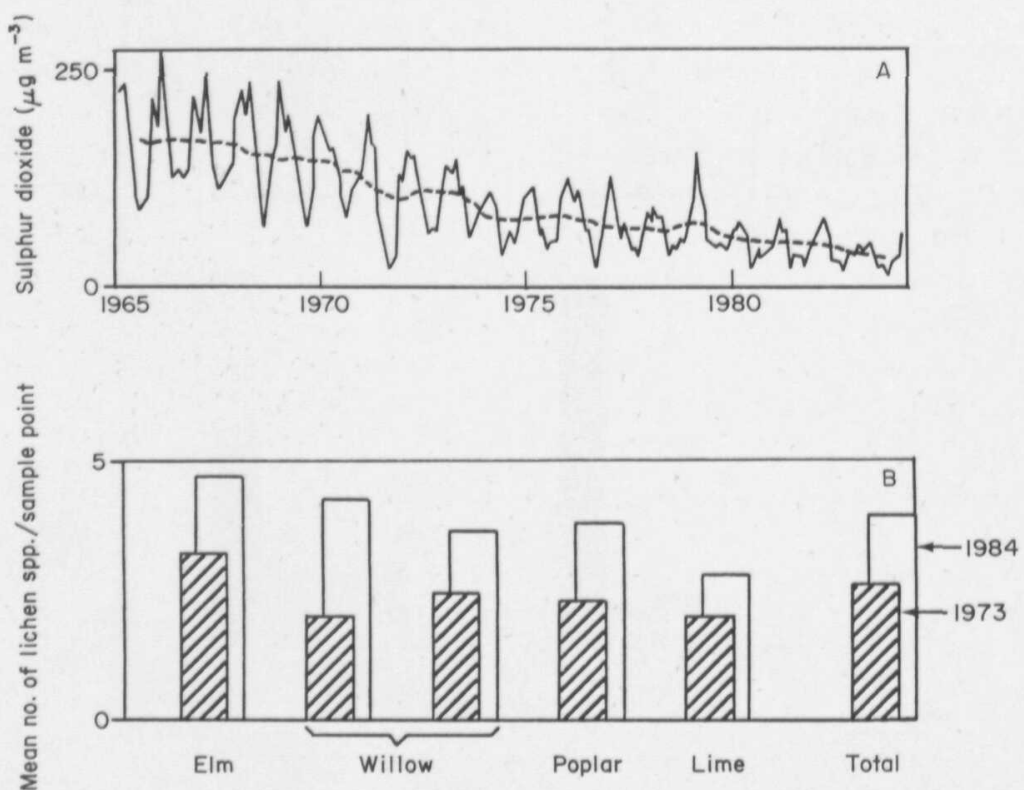

Figure 3. A, Average concentration of sulphur dioxide recorded monthly at Schiedam in ZuidHolland from 1965 to 1983; broken line shows running annual mean. B, Mean number of species of epiphytic lichens recorded at numerous sites in Zuid-Holland on different tree species in the years 1973 and 1984 (both parts redrawn from Bakker et al., 1987). 
- pollution and melanic frequencies. However, the apparently early establishment of the melanism in The Netherlands is noteworthy since during the mid- to late nineteenth century, industrialization was much less intensive and more localized than in northern England.

The frequency of carbonaria has declined quite dramatically in the last 20 or so years. This appears to parallel the change in many populations in northern England and which is best documented at Caldy near Liverpool (Clarke et al., 1985) where carbonaria has declined rapidly from about $90 \%$ to $40 \%$ since 1970 . Cook et al. (1986) show that this change is consistent with a more or less constant selective disadvantage to carbonaria of about $12 \%$ compared to the earlier period. However, at Caldy carbonaria is being replaced largely by typica; insularia increasing from below $1 \%$ up to only about $4 \%$, with each of the three classes being represented (Mani, 1990; C. A. Clarke, personal communication). This suggests that a more complex change in the relative fitnesses of the various genotypes is occurring in The Netherlands where both typica and (darker) insularia are increasing at the expense of carbonaria.

Models of the decline in carbonaria at Caldy have shown that it is closely correlated with a reduction of sulphur dioxide in the locality (Mani, 1990). Fig 3A shows a typical data set illustrating the progressive decline in levels of sulphur dioxide which has occurred since the early 1970s in the Province of Zuid-Holland and elsewhere in The Netherlands. Although sulphur dioxide is not the only significant factor influencing changes in the epiphytic lichen communities in The Netherlands (de Wit, 1983) there is clearly a correlated increase in lichen species diversity on a variety of tree species in Zuid-Holland (Fig. 3B). Small colonies of foliose lichens now occur on the trunks and upper surface of branches in trees in cities in this area. This may be an important factor, together with more general changes in bark colouration, influencing relative crypsis in Biston moths (see discussion in Liebert \& Brakefield, 1987).

Mani (1990) in a modelling approach to examining changes in fitness in the population at Caldy assumes that insularia suffers less loss of fitness with reduction in air pollution than carbonaria. The frequency data from The Netherlands suggest that the darker insularia phenotypes may indeed experience less loss of fitness there and, moreover, that they may have similar fitness to the typica form. Future experimental analyses of moth crypsis will investigate the possibility that changes in the available resting backgrounds for B. betularia in trees in central Holland have led to a switch from a bias towards those giving carbonaria the closest background-matching to a mixture of some favouring darker insularia and some, typica.

\section{ACKNOWLEDGEMENTS}

My great debt to Dhr B. J. Lempke for making his data and knowledge freely available to me will be obvious to all readers. I also thank all the Dutch entomologists who contributed to his survey. I am also most grateful to Tony Liebert for breeding the stocks used for assembling and for valuable assistance with the fieldwork and developing my scoring system. I thank Stephanie Meredith and Frans v. Eysinga for their help in collecting in Amsterdam and Friesland. 


\section{REFERENCES}

BAKKER, A. J., DOBBEN, H. F. VAN, KEURS, W. J. TER \& MEELIS, E., 1987. Terugkeer van epifytische korstmossen in Zuid-Holland. Landschap, 1987: 4-18.

BARKMAN, J. J., 1969. The influence of air pollution on bryophytes and lichens. Air Pollution: 197-209. Wageningen: PUDOC.

BRAKEFIELD, P. M., 1987. Industrial melanism: do we have the answers? Trends in Ecology \&̊ Evolution, 2: $117-122$

BRAKEFIELD, P. M. \& LEES, D. R., 1987. Melanism in Adalia ladybirds and declining air pollution in Birmingham. Heredity, 59: 273-277.

CLARKE, C. A., 1979. Biston betularia, obligate f. insularia indistinguishable from $\mathrm{f}$. carbonaria. Journal of the Lepidopterists' Society, 33: 60-64.

CLARKE, C. A., MANI, G. S. \& WYNNE, G., 1985. Evolution in reverse: clean air and the peppered moth. Biological Journal of the Linnean Society, 26: 189-199.

COOK, L. M., 1981. Manchester and its moths. Biologist, 28: 49-51.

COOK, L. M., MANI, G. S. \& VARLEY, M. E., 1986. Postindustrial melanism in the peppered moth. Science, 231: $611-613$.

CREED, E. R., 1971. Industrial melanism in the two-spot ladybird and smoke abatement. Evolution, 25: 290-293.

DE WIT, T., 1983. Lichens as indicators for air quality. Environmental Monitoring and Assessment, 3: $273-282$.

HEYLAERTS, F. J. M., 1870. Les macrolépidoptères des environs de Bréda. Tijdschrift voor Entomologie, 13. $142-157$.

HOWLETT, R. J. \& MAJERUS, M. E. N., 1987. The understanding of industrial melanism in the peppered moth (Biston betularia) (Lepidoptera: Geometridae). Biological Journal of the Linnean Society, 30: 31-44.

KETTLEWELL, H. B. D., 1973. The Evolution of Melanism. Oxford: Clarendon Press.

LEES, D. R. \& CREED, E. R., 1977. The genetics of the insularia forms of the peppered moth, Biston betularia. Heredity, 39: 67-73.

LEMPKE, B. J., 1970. Catalogus der Nederlandse Macrolepidoptera (Zestiende Supplement). Tijdschrift voor Entomologie, 113: 125-252.

LIEBERT, T. G. \& BRAKEFIELD, P. M., 1987. Behavioural studies on the peppered moth Biston betularia and a discussion of the role of pollution and lichens in industrial melanism. Biological Journal of the Linnean Society, 31: 129-150.

MANI, G. S., 1990. Theoretical models of melanism in Biston betularia - a review. Biological Journal of the Linnean Society, 39: 355-371. 